\section{Penetration Capacity, Color Alteration and Biological Response of Two In-office Bleaching Protocols}

Luciano Tavares Angelo Cintra' ${ }^{1}$ Francine Benetti' ${ }^{1}$ Luciana Louzada Ferreira' ${ }^{1}$ João Eduardo Gomes-Filho ${ }^{1}$, Edilson Ervolino' ${ }^{2}$, Marjorie de Oliveira Gallinari ${ }^{3}$, Vanessa Rahal ${ }^{3}$, André Luiz Fraga Briso ${ }^{3}$
'Endodontics, Araçatuba Dental School, UNESP - Universidade Estadual Paulista, Araçatuba, SP, Brazil ${ }^{2}$ Basic Science, Araçatuba Dental School, UNESP - Universidade Estadual Paulista, Araçatuba, SP, Brazil ${ }^{3}$ Restorative Dentistry, Araçatuba Dental School, UNESP - Universidade Estadual Paulista, Araçatuba, SP, Brazil

Correspondence: Dr. Luciano Tavares Angelo Cintra, R. José Bonifácio, 1193, 16015-050 Araçatuba, SP, Brasil. Tel: +55-18-3636-2867. e-mail: lucianocintra@foa.unesp.br

Key Words: hydrogen peroxide, in-office bleaching, pup inflammation.

\section{Introduction}

In-office bleaching is a popular dental aesthetic treatment option because of its high success rate (1). Several methods and approaches have been described in the literature for bleaching vital teeth, such as different bleaching agents, concentrations, time of application and product presentation (2). Hydrogen peroxide $\left(\mathrm{H}_{2} \mathrm{O}_{2}\right)$ is the main active compound of most commercially available bleaching agents (3), whitens teeth by oxidizing organic structures through reactive oxygen species (ROS) (4).

The use of $\mathrm{H}_{2} \mathrm{O}_{2}$ at high concentrations (25-40\%) leads to tooth color enhancement and reduced shade guide units. Of note, higher the concentration and application time of $\mathrm{H}_{2} \mathrm{O}_{2}$, greater is the ROS production (5), such as superoxide anions $\left(\mathrm{O}^{2-}\right), \mathrm{H}_{2} \mathrm{O}_{2}$, hydroxyl radical $(-\mathrm{OH})$ and $\mathrm{O}_{2}$ (5). The low molecular weight of $\mathrm{H}_{2} \mathrm{O}_{2}$ and its sub products favors the rapid diffusion of these ROS through mineralized dental tissues (4). Here, ROS induce oxidative stress in a time/concentration-dependent fashion (6), at least in part, because of imbalance between the amount of ROS and that of endogenous or exogenous antioxidants (7). This stress, in turn, causes mutation, enzyme inactivation, protein fragmentation and degradation of pulp cells (8), resulting in pain or necrosis (5).

The success of in-office bleaching protocols is directly related to the diffusion capacity of $\mathrm{H}_{2} \mathrm{O}_{2}$ through enamel and dentin (9). However, deeper penetration increases the risk of pulp damage (9). New products based on $20 \%$ $\mathrm{H}_{2} \mathrm{O}_{2}$ were placed on the market, but there are few studies comparing the efficacy and the effects on pulp of this concentration to traditional products (2). It is important to maintain the effectiveness of dental bleaching, however the indicated posology must be evaluated due its biologic safety. Changes in in-office dental bleaching technique may provide alternatives for maintaining its effectiveness and prevent or at least reduce the harmful effects of this therapy on pulp tissue (7).

Considering the great demand for dental bleaching procedures and the aesthetic benefits obtained due this treatment, it is required deeper studies for different $\mathrm{H}_{2} \mathrm{O}_{2}$ protocols considering its final results and their consequences. Therefore, the aim of this study was to evaluate trans-enamel/dentinal penetration of $\mathrm{H}_{2} \mathrm{O}_{2}$, color alteration, and the influence on pulp damage of two inoffice bleaching protocols with $\mathrm{H}_{2} \mathrm{O}_{2}$. The null hypotheses tested were: the concentration of the $\mathrm{H}_{2} \mathrm{O}_{2}$ does not 
influence the trans-enamel/dentinal penetration, the bleaching effectiveness and the pulp damage.

\section{Material and Methods}

\section{In vitro Experiment}

Collection and Standardization of Specimens

Forty-five bovine incisors $(n=45)$ were obtained from animals aged $24-30$ months $(9,10)$. To perform the enamel surface standardization, teeth were analyzed under a stereomicroscope, and those with spots, disparate morphological changes, and excessive wear of the incisor and the presence of cracks were excluded. The selected teeth were cleaned with periodontal curettes, pumice and water. They were fixed on a device attached to a drill platform bench (FGC-16; Ferrari, São Paulo, SP, Brazil) and cut with a diamond tip $(0.8 \mathrm{~mm}$ in diameter; Dinser Ferramentas Diamantadas Ltda, São Paulo, SP, Brazil) under constant irrigation. Cylinders (5.7 $\mathrm{mm}$ in diameter) were created from the middle third of the buccal surface.

The dentinal surface was manually smoothened with 600-grit aluminum oxide sandpaper (T469-SF-Noton, Saint Gobam Abrasives Ltda, Jundiai, SP, Brazil) until 3.5-mmthick discs ( 1.3 and $2.2 \mathrm{~mm}$ of enamel and dentin, respectively), measured by a digital caliper (500 to $144 \mathrm{~B}$, Mitutoyo South America Ltda, Suzano, SP, Brazil), were obtained. The smear layer was removed by applying EDTA solution for $30 \mathrm{~s}$, followed by a rinsed with deionized water.

The specimens were divided into 3 groups according to the bleaching agent $(n=15)$ : BLU (Whiteness HP Blue 20\%); MAX (Whiteness HP Maxx 35\%); and Control group (Placebo gel).

\section{Artificial Pulp Chambers (APCs)}

Each disc was adapted to an APC (9-11). Each APC had upper and lower compartments with 8- and 6-mmdiameter openings, respectively, to allow appropriate positioning and lateral sealing of the specimen. The lower compartment also had lateral perforations for circulation of the bleaching agent and was used to quantify $\mathrm{H}_{2} \mathrm{O}_{2}$ penetration in the specimen. The specimens were attached in the upper compartment of the APCs between two silicone rings (5.60-mm inner diameter, 1.78-mm thickness; Ref. OR 008; Rodimar Rolamentos Ltda, Araraquara, SP, Brazil), which maintained fixation of the disks and sealed with pink wax, restricting lateral penetration of the bleaching agent. The lower compartment side had holes to allow circulation of the solutions that remained in contact with the dentin surface (acetate buffer solution).

\section{In Vitro Bleaching Procedure}

The APCs were individually placed in wells of acrylic cell culture plates filled with 1-mL acetate buffer solution.
The dentinal surface remained in contact with the acetate solution. The specimens were then treated with either $0.04 \mathrm{~mL}$ of $20 \% \mathrm{H}_{2} \mathrm{O}_{2}$ (Whiteness HP Blue) once for 50 min (BLU group), or $0.04 \mathrm{~mL}$ of $35 \% \mathrm{H}_{2} \mathrm{O}_{2}$ (Whiteness $\mathrm{HP}$ Maxx) in three times for 15 min each (MAX group) with a 2-min interval between sessions, or $0.04 \mathrm{~mL}$ of placebo gel (Control group) for $50 \mathrm{~min}$. All procedures were performed in accordance with the manufacturer's instructions (FGM Produtos Odontologicos Ltda, Joinville, SC, Brazil).

\section{Quantification of $\mathrm{H}_{2} \mathrm{O}_{2}$ Penetration}

After the bleaching procedure, $25 \mu \mathrm{L}$ of the acetate buffer solution was removed from each well and mixed with $2,750 \mu \mathrm{L}$ of distilled water, $100 \mathrm{~mL}$ of leucocrystal violet ( $0.5 \mathrm{mg} / \mathrm{mL}$; Sigma Chemical Co, St. Louis, MO, USA), and $50 \mu \mathrm{L}$ of peroxidase $(1 \mathrm{mg} / \mathrm{mL}$, Sigma Chemical Co). The solution was diluted to a final volume of $3 \mathrm{~mL}$ with distilled water.

Penetration was evaluated on the basis of the reaction of $\mathrm{H}_{2} \mathrm{O}_{2}$ with leucocrystal violet, catalyzed by peroxidase enzyme (9). The color of the mixture changes according to the amount of $\mathrm{H}_{2} \mathrm{O}_{2}$. As the signal is proportional to the absorbance of $\mathrm{H}_{2} \mathrm{O}_{2}$, the amount of $\mathrm{H}_{2} \mathrm{O}_{2}$ penetrating the tooth surface and solution in the wells can be indirectly assessed. An ultraviolet visible reflectance spectrophotometer (UV-2450, Shimadzu, Kyoto, Japan) was used for measurements $30 \mathrm{~min}$ after each bleaching session. The calibration factor (CF) was calculated as the ratio of the concentration of the standard solution of $\mathrm{H}_{2} \mathrm{O}_{2}$ to its absorbance. The average $\mathrm{CF}$ was used to calculate the $\mathrm{H}_{2} \mathrm{O}_{2}$ concentration in each specimen.

\section{Color Evaluation}

Color assessment of the same specimens was performed by using an ultraviolet visible spectrophotometer, Model UV-2450 (Shimadzu, Kyoto, Japan), which uses the color model CIE $L^{*} a^{*} b^{*}$ established by the Commission Internacionale l'Éclairage-CIE. For this purpose, we made a black silicone mold containing a central hole, which allowed standard positioning of the specimen during the readings. Three measurements were obtained for each specimen, and the average between them was calculated. The analyses were performed before the initiation of treatment and $24 \mathrm{~h}$ after the bleaching session. The CIE $L^{*} a^{*} b^{*}$ color calculates the distance between two points by using the following formula: $\Delta \mathrm{E}^{*}=\left[\left(\Delta \mathrm{L}^{*}\right)^{2}+\left(\Delta \mathrm{a}^{*}\right)^{2}+\left(\Delta \mathrm{b}^{*}\right)^{2}\right]^{1 / 2}$.

\section{In Vivo Experiment}

\section{Animals}

Twenty male Wistar rats (180-200 g) were used in this study. The animals were housed in a temperature-controlled environment $\left(22{ }^{\circ} \mathrm{C} \pm 1{ }^{\circ} \mathrm{C}, 70 \%\right.$ humidity and $12 \mathrm{~h}$ light- 
dark cycle) and received water and food ad libitum. All the animal procedures were performed in accordance with the Guide for the Care and Use of Laboratory Animals of the National Institutes of Health (Bethesda, MD, USA). The experimental protocol (CEUA-2012-00846) was approved by the Ethics Committee of Universidade Estadual Paulista (UNESP; Araçatuba, SP, Brazil).

\section{In Vivo Bleaching Procedure}

The rats were anesthetized by intramuscular injections of ketamine ( $87 \mathrm{mg} / \mathrm{kg}$; Francotar, Virbac do Brasil Ind. e Com. Ltda; Roseira, SP, Brazil) and xylazine $(13 \mathrm{mg} / \mathrm{kg}$; Rompum, Bayer SA, São Paulo, SP, Brazil) and assigned to two equal groups (12). The BLU group $(n=10)$ underwent one bleaching session with $20 \% \mathrm{H}_{2} \mathrm{O}_{2}$ (Whiteness HP Blue) for 50 min. The MAX group $(n=10)$ underwent three 15-min sessions with $35 \% \mathrm{H}_{2} \mathrm{O}_{2}$ (Whiteness HP Maxx) with a 2-min interval between sessions. Both the protocols were performed according to the manufacturer's recommendations (FGM). The products were applied to three maxillary right molars in both the groups; the contralateral molars served as control group.

\section{Histology}

Two days after the bleaching procedure, the animals were killed with an overdose of the anesthetic solution. The bilateral maxillae were separated, dissected and fixed in 10\% buffered formalin solution for $24 \mathrm{~h}$. The tissues were then dehydrated through a graded series of ethanol, embedded in paraffin, cut into 5- $\mu \mathrm{m}$ sagittal sections, and stained with hematoxylin and eosin (H\&EE).

Histomorphometry was performed under light microscopy ( $\times 400$ magnification; DM4000 B, Leica Microsystems, Wetzlar, Germany). The coronal pulp was divided into occlusal, middle and cervical thirds, and the radicular pulp was divided into cervical, middle and apical thirds. The intensity of inflammation in each third was scored according to the inflammatory infiltrate: 1 , no or few cells (normal); $2,<25$ cells (mild); $3,25-125$ cells (moderate); $4,>125$ cells (severe or necrosis) (12).

\section{Statistical Analysis}

Data were collected and analyzed by a single calibrated operator in a blinded manner. Normality and homoscedasticity were verified. Analysis of variance (ANOVA) and Student $t$-test were used to analyze hard-tissue penetration and color alteration, while one-way ANOVA and Mann-Whitney $U$-test were used for statistical comparisons of pulp damage at the significance level of $5 \%(\square=0.05)$.

\section{Results}

Trans-Enamel/Dentinal Penetration of $\mathrm{H}_{2} \mathrm{O}_{2}$ and Color Alteration

BLU, MAX and control group had mean penetration values of $4.42 \pm 0.46,6.14 \pm 0.67$ and $0.04 \pm 0.03 \mu \mathrm{g} / \mathrm{mL}$, respectively. Student $t$-test revealed significant differences for trans-enamel/dentinal penetration of hydrogen peroxide between the groups $(p<0.05)$, showing that higher the concentration, higher the penetration through hard dental tissue (Table 1).

The analysis of $\Delta \mathrm{a}, \Delta \mathrm{b}, \Delta \mathrm{L}$ and $\Delta \mathrm{E}$ showed significant differences for color alteration between Control group as compared with BLU and MAX $(p<0.05)$. However, the $B L U$ and MAX groups showed similar results to all analysis (p>0.05) (Table 1).

\section{Inflammatory Response}

The control group exhibited well-defined acellular and cell-rich layers under an intact odontoblast layer and even distribution of cell components, blood vessels, and extracellular matrix structures in the dental pulp (Fig. 1A-C).

All the BLU specimens showed various changes in the coronal pulp. Seven and three specimens showed moderate and severe inflammation or necrosis, respectively, in the occlusal third, with absence of cells and the odontoblast layer as well as tissue disorganization in some pulp horns (Fig. 1D). The middle third showed moderate to mild inflammation (Fig. 1E). The cervical thirds of coronal pulp had mild inflammation, narrowed odontoblast layer and congested blood vessels (Fig. 1F). Two specimens showed mild inflammation in the cervical third of the radicular pulp.

In the MAX group, eight specimens exhibited necrosis in the pulp horns (Fig. 1G) and severe or moderate inflammation in the middle third, with an absent odontoblast layer and congested blood vessels (Fig. 1H). Three and five specimens showed moderate and mild inflammation, respectively, in the cervical third of the coronal pulp (Fig. 1I). Three specimens showed mild inflammation in the cervical third of the radicular pulp.

In the upper two-thirds of the coronal pulp, a significant difference in inflammatory response was observed between

Table 1. Mean and standard deviation (SD) of $\mathrm{H}_{2} \mathrm{O}_{2}$ penetration and color alteration

\begin{tabular}{lccccc}
\hline \multirow{2}{*}{$\begin{array}{l}\text { Group } \\
(\mathrm{n}=15)\end{array}$} & $\begin{array}{c}\mathrm{H}_{2} \mathrm{O}_{2} \\
\text { Penetration } \\
\left(\text { Mean } \pm \mathrm{SD}^{*}\right)\end{array}$ & $\square \mathrm{a}$ & $\square \mathrm{b}$ & $\square \mathrm{L}$ & $\square \mathrm{E}$ \\
\cline { 3 - 6 } Control & $0.04 \pm 0.03^{\mathrm{a}}$ & $-0.13 \pm 0.28^{\mathrm{a}}$ & $-0.22 \pm 0.71^{\mathrm{a}}$ & $0.44 \pm 0.91^{\mathrm{a}}$ & $1.17 \pm 0.63^{\mathrm{a}}$ \\
BLU & $4.42 \pm 0.46^{\mathrm{b}}$ & $0.23 \pm 0.31^{\mathrm{b}}$ & $-1.22 \pm 1.13^{\mathrm{b}}$ & $3.86 \pm 0.94^{\mathrm{b}}$ & $4.22 \pm 0.85^{\mathrm{b}}$ \\
MAX & $6.14 \pm 0.67^{\mathrm{c}}$ & $0.25 \pm 0.28^{\mathrm{b}}$ & $-1.97 \pm 1.24^{\mathrm{b}}$ & $4.14 \pm 1.31^{\mathrm{b}}$ & $4.83 \pm 0.88^{\mathrm{b}}$ \\
\hline
\end{tabular}

* Different letters indicate statistically significant diferences in the column $(\mathrm{p}<0.05)$. 
$B L U$ and MAX groups $(p<0.05)$. The intensity decreased apically (Table 2). Overall, BLU and MAX had median scores of 3 and 4 , respectively in the occlusal third and, 2 and 3 , in middle third of the coronal pulp $(p<0.05)$.

\section{Discussion}

The high concentration gel influence $\mathrm{H}_{2} \mathrm{O}_{2}$ penetration and induced more severe alterations in the pulp tissues, however not obtained more bleaching effectiveness. In vivo and in vitro studies are among the experimental models used to analyze the alterations caused by $\mathrm{H}_{2} \mathrm{O}_{2}$ in the pulp tissue and the level of penetration through enamel and dentin reaching the pulp chamber $(9,13)$. Bovine teeth were used because human teeth are more susceptible to $\mathrm{H}_{2} \mathrm{O}_{2}$ penetration than bovine (10), as well as rat teeth that allows the analysis on dental pulp (12).

The literature has shown that bleaching agents at high concentrations can produce injuries to the pulpal tissue $(5,12,13)$, for this reason it was used two different bleaching agents, one containing 35\% and the other containing $20 \%$ hydrogen peroxide. In this study, we found significant differences in bovine teeth hard-tissue penetration between MAX and BLU, which can be attributed to the different concentrations of the $\mathrm{H}_{2} \mathrm{O}_{2}$. The result showed that higher the $\mathrm{H}_{2} \mathrm{O}_{2}$ concentration, deeper is the penetration through enamel and dentin, rejecting the first
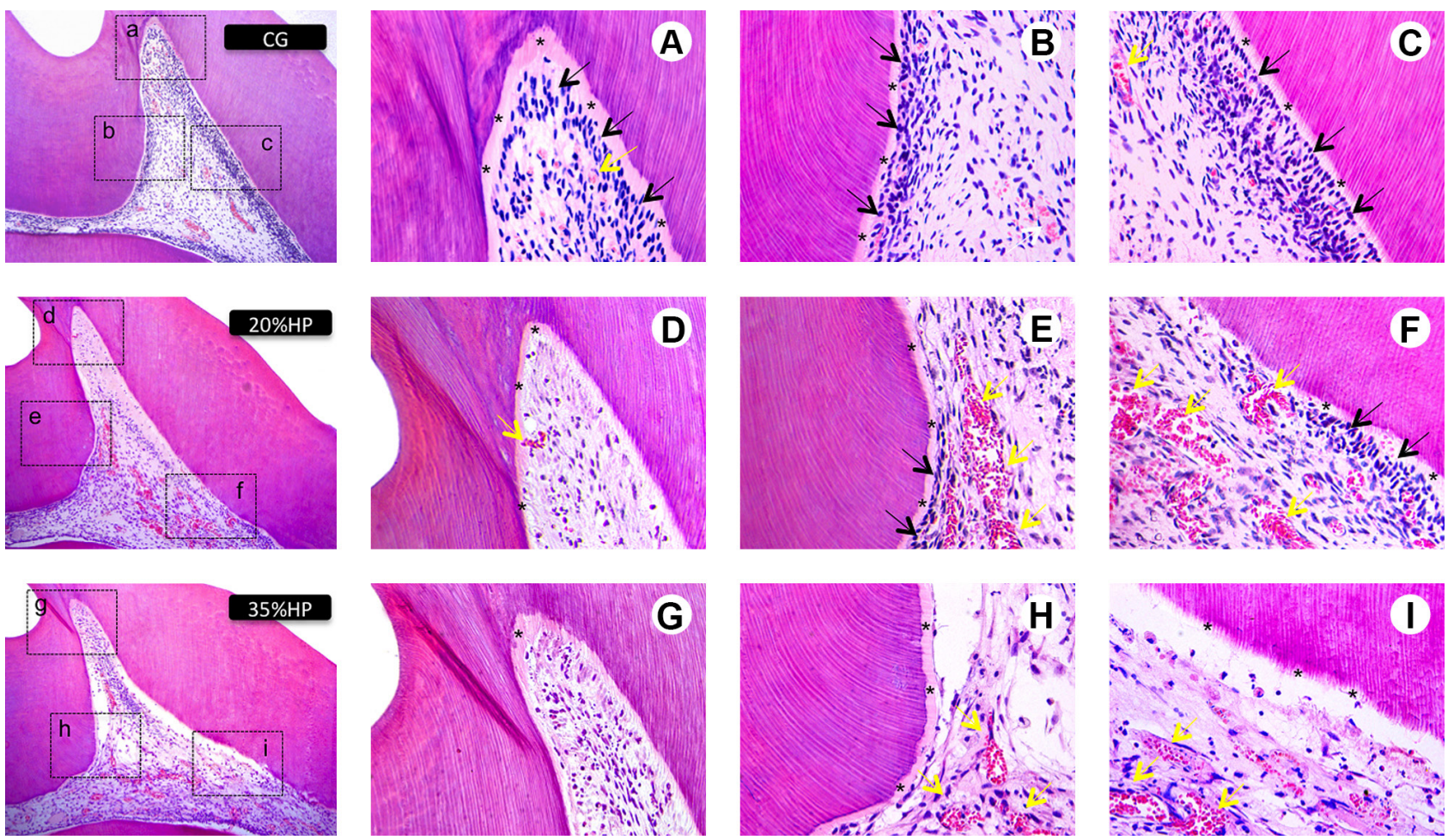

Figure 1. Representative images of HetE-stained sections 2 days after bleaching. The three right panels in each row are magnified views ( $\times 400$ ) of the images ( $\times 100$ magnification) from the CG (A-C), BLU (D-F) and MAX (G-I) groups. The asterisks indicate predentin, the black arrows depict the odontoblastic layer and the yellow arrows show pulp cells and blood vessels. 
Although it is not a frequent coordinate influenced by the bleaching procedure, the statistical analysis detected that $\Delta$ a values of bleached groups differed from the control

Table 2. Inflammation Intensity among the experimental groups

\begin{tabular}{|c|c|c|c|c|c|}
\hline Third & Score & CG & BLU & MAX & $\begin{array}{c}\text { Statistical } \\
\text { analysis }\end{array}$ \\
\hline \multicolumn{6}{|l|}{$\begin{array}{l}\text { Coronal } \\
\text { pulp }\end{array}$} \\
\hline \multirow{5}{*}{ Occlusal } & 1 & $10 / 10$ & $0 / 10$ & $0 / 10$ & \multirow{5}{*}{$\begin{array}{c}\text { Mann Whitney } \\
\text { BLU × MAX: } \\
\text { p=0.028 }\end{array}$} \\
\hline & 2 & $0 / 10$ & $0 / 10$ & $0 / 10$ & \\
\hline & 3 & $0 / 10$ & $7 / 10$ & $2 / 10$ & \\
\hline & 4 & $0 / 10$ & $3 / 10$ & $8 / 10$ & \\
\hline & Median & 1 & $3^{\mathrm{a}}$ & $4^{\mathrm{b}}$ & \\
\hline \multirow{5}{*}{ Middle } & 1 & $10 / 10$ & $2 / 10$ & $0 / 10$ & \multirow{5}{*}{$\begin{array}{c}\text { Mann Whitney } \\
\text { BLU × MAX: } \\
\text { p=0.024 }\end{array}$} \\
\hline & 2 & $0 / 10$ & $4 / 10$ & $2 / 10$ & \\
\hline & 3 & $0 / 10$ & $4 / 10$ & $5 / 10$ & \\
\hline & 4 & $0 / 10$ & $0 / 10$ & $3 / 10$ & \\
\hline & Median & 1 & $2^{\mathrm{a}}$ & $3^{\mathrm{b}}$ & \\
\hline \multirow{5}{*}{ Cervical } & 1 & $10 / 10$ & $2 / 10$ & $2 / 10$ & \multirow{5}{*}{$\begin{array}{c}\text { Mann Whitney } \\
\text { BLU × MAX: } \\
\text { p }=0.283\end{array}$} \\
\hline & 2 & $0 / 10$ & $8 / 10$ & $5 / 10$ & \\
\hline & 3 & $0 / 10$ & $0 / 10$ & $3 / 10$ & \\
\hline & 4 & $0 / 10$ & $0 / 10$ & $0 / 10$ & \\
\hline & Median & 1 & $2^{\mathrm{a}}$ & $2^{\mathrm{a}}$ & \\
\hline \multicolumn{6}{|l|}{$\begin{array}{l}\text { Radicular } \\
\text { pulp }\end{array}$} \\
\hline \multirow{5}{*}{ Cervical } & 1 & $10 / 10$ & $8 / 10$ & $7 / 10$ & \multirow{5}{*}{$\begin{array}{c}\text { Mann Whitney } \\
\text { BLU × MAX: } \\
\text { p =0.614 }\end{array}$} \\
\hline & 2 & $0 / 10$ & $2 / 10$ & $3 / 10$ & \\
\hline & 3 & $0 / 10$ & $0 / 10$ & $0 / 10$ & \\
\hline & 4 & $0 / 10$ & $0 / 10$ & $0 / 10$ & \\
\hline & Median & 1 & $1^{\mathrm{a}}$ & $1^{\mathrm{a}}$ & \\
\hline \multirow{5}{*}{ Middle } & 1 & $10 / 10$ & $10 / 10$ & $10 / 10$ & \multirow{5}{*}{$\begin{array}{c}\text { Mann Whitney } \\
\text { BLU × MAX: } \\
\text { p }=1\end{array}$} \\
\hline & 2 & $0 / 10$ & $0 / 10$ & $0 / 10$ & \\
\hline & 3 & $0 / 10$ & $0 / 10$ & $0 / 10$ & \\
\hline & 4 & $0 / 10$ & $0 / 10$ & $0 / 10$ & \\
\hline & Median & 1 & $1^{\mathrm{a}}$ & $1^{\mathrm{a}}$ & \\
\hline \multirow{5}{*}{ Apical } & 1 & $10 / 10$ & $10 / 10$ & $10 / 10$ & \multirow{5}{*}{$\begin{array}{c}\text { Mann Whitney } \\
\text { BLU } \times \text { MAX: } \\
\text { p }=1\end{array}$} \\
\hline & 2 & $0 / 10$ & $0 / 10$ & $0 / 10$ & \\
\hline & 3 & $0 / 10$ & $0 / 10$ & $0 / 10$ & \\
\hline & 4 & $0 / 10$ & $0 / 10$ & $0 / 10$ & \\
\hline & Median & 1 & $1^{\mathrm{a}}$ & $1^{\mathrm{a}}$ & \\
\hline
\end{tabular}

Different letters in the same row indicate statistically significant differences in median score $(\mathrm{p}<0.05)$. group. It is believed that this reading may have detected any dyes in the bleaching gels used topically on the dental enamel, not influencing the aesthetic obtained with the treatment.

The similar results between MAX and BLU products, which might be explained by the diffusion coefficients, application time and bleaching agents concentration. Borges et al. (19) demonstrated that $\mathrm{H}_{2} \mathrm{O}_{2}$ at the concentration of $35 \%$ has bleaching effectiveness greater than the concentration of 20\% when both were applied for $30 \mathrm{~min}$. However, de Almeida et al. (2), obtained similar results to our study observing the same bleaching effectiveness when $\mathrm{H}_{2} \mathrm{O}_{2}$ $35 \%$ and $20 \%$ was applied for $45 \mathrm{~min}$. It means that a less concentrated product applied for a longer time can produce results as good as a higher concentrated product $(2,18)$. Besides the concentration difference and the application time, the similar color alteration between both experimental groups might also be related to different viscosity of the hydrogen peroxide gels (20).

The oxidizing ability of $\mathrm{H}_{2} \mathrm{O}_{2}$ may be responsible for the reduction in dentinal organic components when bleaching product is applied directly to dentin (8). Bleaching agent penetration occurs mainly because of the low molecular mass and ability to denature proteins, increasing ion movement through tooth structure (11), but it is also influenced by tooth density and dentinal tubule diameter (21).

After applying a bleaching agent, changes in the prismatic structure and biochemical properties, such as loss of carbonate and proteins, of enamel and dentin are notable. The loss becomes greater with enhanced proteolytic activity and reduced collagen, increasing the number of diffusion channels and cell permeability (22), and the $\mathrm{pH}$ of Whiteness HP Blue and HP Max with or without reapplications remains above the critical value for enamel ( $\mathrm{pH}$ 5.5) even after the application time, influencing the penetration of $\mathrm{H}_{2} \mathrm{O}_{2}$. Therefore, possible pulp damage caused by ROS-promoted oxidation should be checked after bleaching (8). Despite the penetration power of $\mathrm{H}_{2} \mathrm{O}_{2}$, its diffusion through dentinal tubules of teeth with vital pulps may be prevented by dentinal fluid flow produced by intrapulpal pressure, cytoplasmic extensions of odontoblasts and other intratubular components (23).

In the present study, the histological findings showed that higher concentration of $\mathrm{H}_{2} \mathrm{O}_{2}$ induced greater pulp changes, rejecting the third null hypothesis. The MAX group had disorganized odontoblast layer and pulp with areas of necrosis, liquefaction, absence of cells, intense inflammatory infiltrate, and dilated and congested vessels, which goes against to a previous research that shows pulp alterations until pulp necrosis as increasing the number of sessions (12).

In-office bleaching with $35 \% \mathrm{H}_{2} \mathrm{O}_{2}$ for $30 \mathrm{~min}$ 
causes severe pulp reactions such as dentin deposition, inflammation, and damage to odontoblast-like cells, and internal resorption in dogs (13). However, human premolars bleached with $38 \% \mathrm{H}_{2} \mathrm{O}_{2}$ mostly show normal dental pulp and no inflammation (23). Further, human incisors bleached with $38 \% \mathrm{H}_{2} \mathrm{O}_{2}$ become sensitive, but not treated human premolars (5). These differences may be related to the thickness of the hard tissues and their structural features.

Results obtained in animal studies cannot be extrapolated directly to human teeth $(5,22,23)$, especially because of the difference in enamel thickness between humans and rats $(2.5 \mathrm{~mm}$ vs. $100 \mu \mathrm{m})(24)$. Rat teeth are less dense than human teeth and extremely porous, allowing easy diffusion of fluids and dyes (24). However, in a previous study, human mandibular incisors subjected to repeated bleaching demonstrated large areas of necrosis in the coronal and radicular pulp, with mild inflammation (5). Considering the similarity of these results with our findings, rat molars may be a suitable model to predict the results of procedures performed in human mandibular incisors.

It was found that most of the treated specimens exhibited inflammatory infiltrate, congested blood vessels, disorganized pulp especially in the pulp horns of both the groups, and large areas of necrosis in the MAX group. This suggests that the intense and rapid penetration of dental hard tissue by $\mathrm{H}_{2} \mathrm{O}_{2}$ may be beyond the capacity and speed of the pulp's protective mechanism, resulting in an immediate response to this highly aggressive compound. The problem lies in not knowing exactly the concentration of $\mathrm{H}_{2} \mathrm{O}_{2}$ that the dental pulp can tolerate without damage (13). However, our results suggest that application of high concentrations of $\mathrm{H}_{2} \mathrm{O}_{2}$ cause intense changes in dental tissues (25).

It was also shown that the concentrations of bleaching agents are more related to the inflammatory response intensity than to the bleaching efficacy. Thus, the results show that it is possible to have a variety of bleaching treatments and protocols, obtaining a similar aesthetic result with less damage to the dental tissues.

This study indicates that in-office bleaching protocols using lower concentrations of hydrogen peroxide should be preferred due to their reduced trans-enamel/dentinal penetration causing less pulp damage, and providing the same bleaching efficiency.

\section{Resumo}

0 peróxido de hidrogênio $\left(\mathrm{H}_{2} \mathrm{O}_{2}\right)$ é capaz de penetrar pelos tecidos dentários, alterando a coloração destes, e causar danos a polpa. Este estudo avaliou a penetração por esmalte e dentina, a alteração de cor e a reposta tecidual pulpar, provocadas pelo uso de duas concentrações de $\mathrm{H}_{2} \mathrm{O}_{2} \mathrm{em}$ protocolos de clareação dentária de consultório. Discos de dentes bovinos em câmaras pulpares artificiais receberam géis clareadores para avaliação da penetração por esmalte e dentina e da alteração de cor, formando os grupos: $\mathrm{BLU}\left(\mathrm{H}_{2} \mathrm{O}_{2} 20 \%\right.$ - 1x50 min, Whiteness HP Blue); $\mathrm{MAX}\left(\mathrm{H}_{2} \mathrm{O}_{2}\right.$ $35 \%$ - 3x15 min, Whiteness HP Maxx); e Controle (gel placebo - 1 x50 $\mathrm{min}$ ). A penetração por esmalte e dentina foi quantificada baseada na reação do $\mathrm{H}_{2} \mathrm{O}_{2}$ com o corante violeta leucocristal, e a alteração de cor foi analisada pelo sistema CIELab. Vinte ratos Wistar foram divididos em dois grupos (BLU e MAX), e tiveram os molares direito superiores tratados com os mesmos protocolos do estudo in vitro; os molares superiores do lado esquerdo serviram de controle. Após 2 dias, os animais foram eutanasiados e as maxilas examinadas por microscopia de luz. Foram atribuidos escores ao infiltrado inflamatório (1, ausente; 2 , leve; 3 , moderado; 4 severo ou necrose). Os dados foram submetidos a testes estatísticos $(\alpha=0,05)$. 0 grupo MAX apresentou maior penetração de $\mathrm{H}_{2} \mathrm{O}_{2}$ por esmalte e dentina $(p<0,05)$. A alteração de cor foi semelhante nos grupos clareados $(p>0,05)$, mas diferente quando comparados grupos clareados com controle $(p<0,05)$. MAX apresentou inflamação severa nos terços superiores da polpa coronária, e BLU apresentou inflamação moderada $(p<0,05)$. Assim, protocolo para procedimento clareador de consultório utilizando baixas concentrações de $\mathrm{H}_{2} \mathrm{O}_{2}$ deve ser de escolha na clínica, por reduzir a penetração por esmalte e dentina, causando menos danos à polpa, e proporcionar mesma eficiência clareadora.

\section{Acknowledgements}

This work was supported by The São Paulo State Research Foundation (FAPESP- grant \#2011/13709-2 and 2013/25163-0).

\section{References}

1. Briso AL, Gonçalves RS, Costa FB, Gallinari MO, Cintra LT, Santos PH. Demineralization and hydrogen peroxide penetration in teeth with incipient lesions. Braz Dent J 2015;26:135-140.

2. Almeida LCAG, Soares DG, Gallinari MO, Costa CAS, Santos PH, Briso ALF. Color alteration, hydrogen peroxide diffusion, and cytotoxicity caused by in-office bleaching protocols. Clin Oral Investig 2015;19:673-680.

3. Rodrigues LM, Vansan LP, Pécora JD, Marchesan MA. Permeability of different groups of maxillary teeth after 38\% hydrogen peroxide internal bleaching. Braz Dent J 2009;20:303-306.

4. Eimar $H$, Siciliano R, Abdallah MN, Nader SA, Amin WM, Martinez $\mathrm{PP}$, et al.. Hydrogen peroxide whitens teeth by oxidizing the organic structure. J Dent 2012;40 Suppl 2:e25-e33.

5. Costa CAS, RiehI H, Kina JF, Sacono NT, Hebling J. Human pulp responses to in-office tooth bleaching. Oral Surg Oral Med Oral Pathol Oral Radiol Endod 2010;109:e59-e64.

6. Matsui S, Takahashi C, Tsujimoto Y, Matsushima K. Stimulatory effects of low-concentration reactive oxygen species on calcification ability of human dental pulp cells. J Endod 2009;35:67-72.

7. Soares DG, Basso FG, Pontes EC, Garcia LD, Hebling J, de Souza Costa CA. Effective tooth bleaching protocols capable of reducing $\mathrm{H} 2 \mathrm{O} 2$ diffusion through enamel and dentine. J Dent 2014;42:351-358.

8. Trindade FZ, Ribeiro APD, Sacono NT, Oliveira CF, Lessa FC, Hebling J, et al.. Trans-enamel and trans-dentinal cytotoxic effects of a $35 \% \mathrm{H} 202$ bleaching gel on cultured odontoblast cell lines after consecutive applications. Int Endod J 2009;42:516-524.

9. Briso ALF, Lima APB, Gonçalves RS, Gallinari MO, dos Santos PH. Transenamel and transdentinal penetration of hydrogen peroxide applied to cracked or microabrasioned enamel. Oper Dent 2014;39:166173.

10. Camargo SEA, Valera MC, Camargo CHR, Mancini MNG, Menezes MM. Penetration of $38 \%$ hydrogen peroxide into the pulp chamber in bovine and human teeth submitted to office bleach technique. J Endod 2007;33:1074-1077.

11. Palo RM, Bonetti-Filho I, Valera MC, Camargo CHR, Camargo SEA, Moura-Netto $C$, et al.. Quantification of peroxide ion passage in dentin, enamel, and cementum after internal bleaching with hydrogen peroxide. Oper Dent 2012;37:660-664.

12. Cintra LT, Benetti $F$, da Silva Facundo AC, Ferreira LL, Gomes-Filho JE, Ervolino $E_{\text {, et }}$ al.. The number of bleaching sessions influences pulp tissue damage in rat teeth. J Endod 2013;39:1576-1580.

13. Seale NS, McIntosh JE, Taylor AN. Pulpal reaction to bleaching of teeth 
in dogs. J Dent Res 1981;60:948-953.

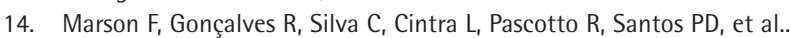
Penetration of hydrogen peroxide and degradation rate of different bleaching products. Oper Dent 2015:40:72-79.

15. Joiner A. The bleaching of teeth: a review of the literature. J Dent 2006;34:412-419.

16. Giannini $M$, Silva AP, Cavalli $V$, Paes Leme AF. Effect of carbamide peroxide-based bleaching agents containing fluoride or calcium on tensile strength of human enamel. J Appl Oral Sci 2006;14:82-87.

17. Briso ALF, Fonseca MSM, de Almeida LCAG, Mauro SJ, dos Santos PH. Color alteration in teeth subjected to different bleaching techniques. Laser Physics 2010;20:2066-2069.

18. Dietschi D, Benbachir N, Krejci I. In vitro colorimetric evaluation of the efficacy of home bleaching and over-the-counter bleaching products. Quintessence Int 2010;41:505-516.

19. Borges AB, Zanatta RF, Barros AC, Silva LC, Pucci CR, Torres CR. Effect of hydrogen peroxide concentration on enamel color and microhardness. Oper Dent 2015;40:96-101.

20. Haywood VB. Nightguard vital bleaching: current information and research. Esthet Dent Update 1990;1:20-25.
21. Zimmerman B, Datko L, Cupelli M, Alapati S, Dean D, Kennedy M. Alteration of dentin-enamel mechanical properties due to dental whitening treatments. J Mech Behav Biomed Mater 2010;3:339-346.

22. D'Amario $M$, D'Attilio $M$, Baldi $M$, De Angelis $F$, Marzo G, Vadini $M$, et al.. Histomorphologic alterations of human enamel after repeated applications of a bleaching agent. Int J Immunopathol Pharmacol 2012;25:1021-1027.

23. Kina JF, Huck C, Riehl H, Martinez TC, Sacono NT, Ribeiro AP, et al. Response of human pulps after professionally applied vital tooth bleaching. Int Endod J 2010;43:572-580.

24. Tanaka R. The morphological study of experimental caries produced in rat molars. Tsurumi Shigaku 1989;15:183-199.

25. Coldebella CR, Robeiro APD, Sacono NT, Trindade FZ, Hebling J, Costa CAS. Indirect cytotoxicity of a 35\% hydrogen peroxide bleaching gel on cultures odontoblast-like cells. Braz Dent J 2009;20:267-274.

Received December 10, 2015 Accepted January 22, 2016 